\title{
Chapter 32 \\ Reformulating Ceramic Body \\ Composition to Improve Energy \\ Efficiency in Brick Manufacture
}

\author{
G. Wie-Addo, A. H. Jones, S. Palmer, V. Starinieri, J. Renshaw, \\ and P. A. Bingham
}

\begin{abstract}
The influence of inorganic minerals (colemanite and nepheline syenite) as additives for sustainable clay brick manufacture has been examined. Each additive was added at $4 \mathrm{wt} \%$ to $96 \mathrm{wt} \%$ brick clay and samples were fired to $950{ }^{\circ} \mathrm{C}$ and $1040{ }^{\circ} \mathrm{C}$ and then compared with samples of $100 \%$ brick clay. Multiple analytical techniques (X-ray fluorescence, dilatometry, boiling water absorption, volumetric shrinkage, and mercury porosimetry) were used for analysis. Dilatometry shows that the additives influenced the temperature at which shrinkage began and the extent of that shrinkage. The use of colemanite reduced the temperature at which the shrinkage began by $120{ }^{\circ} \mathrm{C}$ and nepheline syenite reduced it by $20{ }^{\circ} \mathrm{C}$. A linear shrinkage in dilatometry of $1 \%$ (from the maximum expanded length) was achieved at $1000{ }^{\circ} \mathrm{C}$ for $100 \%$ clay, $875{ }^{\circ} \mathrm{C}$ for colemanite additions and $970{ }^{\circ} \mathrm{C}$ for nepheline syenite additions. However, for samples fired at $1040{ }^{\circ} \mathrm{C}$ for $2 \mathrm{~h}$ colemanite containing samples had significantly lower volumetric shrinkage and higher water absorption than $100 \%$ clay and nepheline syenite samples, suggesting the presence of higher amounts of open porosity caused by the decomposition of the colemanite on heating. Samples containing nepheline syenite had a lower volumetric shrinkage but also a marginally lower water absorption than the $100 \%$ clay. The further optimisation of these or similar additives could potentially provide energy saving opportunities and reductions in $\mathrm{CO}_{2}$ emissions for brick manufacturers.
\end{abstract}

Keywords Clay bricks $\cdot$ Energy savings $\cdot$ Inorganic mineral additives

G. Wie-Addo ( $\varangle) \cdot$ A. H. Jones · V. Starinieri · P. A. Bingham

Materials and Engineering Research Institute, Sheffield Hallam University, Sheffield S1 1WB, UK e-mail: gloria.wie-addo@student.shu.ac.uk

V. Starinieri

e-mail: Starvinc@gmail.com

S. Palmer · J. Renshaw

Wienerberger Ltd, Wienerberger House, Brooks Drive, Cheadle Royal Business Park, Cheshire SK8 3SA, UK

I. Mporas et al. (eds.), Energy and Sustainable Futures, Springer Proceedings in Energy, https://doi.org/10.1007/978-3-030-63916-7_32 


\subsection{Introduction}

Energy is an important factor for the ceramic sector, the key role of the thermal treatment of raw materials in activating the "physical-mineralogical transformation processes" to create the desired properties [1].

Gas combustion, which accounts for 70-80\% energy use in ceramic manufacture contributes substantially to the overall $\mathrm{CO}_{2}$ and greenhouse gas (GHS) released into the atmosphere. These are major contributors to global warming and if left unabated might result in devastating harm to the environment. This has brought about the commitment to minimize $\mathrm{CO}_{2}$ emissions in the ceramic sector through the 2050 decarbonisation plan which intends to address three major categories significant to the ceramic sector. Thus, the raw materials, energy efficiency and $\mathrm{CO}_{2}$ reduction are addressed here through breakthrough technologies of which raw materials and processing are key [2].

This paper focuses on making changes to the raw materials used to make bricks (the clay body) to meet the $\mathrm{CO}_{2}$ emission reduction targets set by the de-carbonation plan. Varying the clay composition using additives is an established way to alter clay properties such as plasticity, colour etc. or, in this case, reducing energy consumption in manufacture. However, identifying the right additive while maintaining the minimum brick properties is not straight forward since international standard bodies such as ASTM and EU regulate these properties [3].

Among the various clay additives identified in the literature [4], the use of colemanite $\left(2 \mathrm{CaO} .3 \mathrm{~B}_{2} \mathrm{O}_{3} .5 \mathrm{H}_{2} \mathrm{O}\right)$ and nepheline syenite $\left(\mathrm{K}_{1.37} \mathrm{Na}_{6}\left(\mathrm{AlSiO}_{4}\right)_{8}\right)$ containing materials have gained much attention. This is due to their high fluxing content of fluxing elements including $\mathrm{Ca}, \mathrm{Na}, \mathrm{Mg}$ and $\mathrm{K}$ [5]. In clay body manufacture the presence of these fluxing agents can create lower melting point phases during firing, enhancing sintering behaviour and properties while using lower firing temperatures. The literature shows the effect of these additives' incorporation into semi-vitreous, glass and glass ceramic products [6-8]. The use of these additives enhanced vitrification, reduced internal stress caused by free quartz in clay and reduced the required firing temperature by $80{ }^{\circ} \mathrm{C}-120^{\circ} \mathrm{C}$. The use of $1 \%$ colemanite was able to reduce the firing temperature by $50{ }^{\circ} \mathrm{C}$ in porcelain bodies without affecting product quality $[5,7,9-12]$. However, the incorporation of the additives into clay brick composition has not been reported.

This study aims to assess the effect of adding $4 \mathrm{wt} \%$ of these inorganic additives on the firing behaviour and properties of clay bricks.

\subsection{Experimental Procedures}

Cretaceous age clay mined in the south-eastern part of UK, sourced from Wienerberger Ltd and inorganic minerals, colemanite $\left(2 \mathrm{CaO} .3 \mathrm{~B}_{2} \mathrm{O}_{3} .5 \mathrm{H}_{2} \mathrm{O}\right)$ and nepheline syenite $\left(\mathrm{K}_{1.37} \mathrm{Na}_{6}\left(\mathrm{AlSiO}_{4}\right)_{8}\right)$ were separately dried in an oven at $120{ }^{\circ} \mathrm{C}$ for $48 \mathrm{~h}$. 
$4 \mathrm{wt} \%$ of each dried additive was weighed and mixed with $96 \mathrm{wt} \%$ dried clay then milled in a Retzsch vibratory disc mill for $1 \mathrm{~min}$ at $800 \mathrm{rpm}$ into a fine powder. The dry powders were mixed with $21 \%$ distilled water to provide sufficient plasticity for shaping. A hydraulic press with 7 tonnes force was applied to $8.3 \mathrm{~g}$ of the composition to form a $20 \mathrm{~mm}$ dimeter, $5 \mathrm{~mm}$ thick cylindrical pellet. After shaping, the green body dimensions were recorded in the "as-pressed" condition. Samples were then left on a bench and further dried in an oven $\left(100{ }^{\circ} \mathrm{C}\right)$ for approximately $36 \mathrm{~h}$ to gradually eliminate water. The dry cylinders were fired to $950{ }^{\circ} \mathrm{C}$ or $1040{ }^{\circ} \mathrm{C}$ at $1{ }^{\circ} \mathrm{C} / \mathrm{min}$ and held for $2 \mathrm{~h}$ at the top temperatures before cooling at the same rate.

Chemical analysis of the raw materials and the fired bodies using XRF fused bead technique was carried out as described elsewhere [13]. Dilatometry (NETZSCH DIL 402SE) was used to measure the linear dimensional changes between $35^{\circ} \mathrm{C}-1050$ ${ }^{\circ} \mathrm{C}$ with a heating rate of $5{ }^{\circ} \mathrm{C} / \mathrm{min}$. A rod of $25 \mathrm{~mm}$ length and $6 \mathrm{~mm}$ diameter of unfired material was used for dilatometry. Volumetric shrinkage measurement were determined on cylindrical $(20 \times 5 \mathrm{~mm})$ test pieces in the wet, dry, and fired conditions. The temperature at which the shrinkage began was taken as the point at which the expansion rate $(\mathrm{dL} / \mathrm{dt})$ becomes negative. As a comparative measure of the shrinkage at the highest temperatures, the temperature at which each sample showed a $1 \%$ shrinkage from its maximum value was noted. Additionally, the level of shrinkage (measured from the maximum level) at $1000{ }^{\circ} \mathrm{C}$ was noted. The boiling water absorption of fired samples was measured according to BS EN 772-7. The boiling test results reported are the averages of 3 sample measurement. Mercury porosimetry was used to determine the intrudable pore volume and the distribution of pores sizes. The intrusion tests were carried out using Pascal 140/240 system with mercury angle at 140 degree.

\subsection{Results and Discussions}

\subsubsection{Chemical Analysis}

XRF showed that colemanite and nepheline syenite had low levels of $\mathrm{Fe}_{2} \mathrm{O}_{3}$ not greater than $1 \%$. This result agrees with previous studies [12]. The XRF used for this analysis could not detect boron because the X-ray energy is below the instrument's minimum detection level. However, the level of boron present can be inferred from the formula for colemanite $\left(2 \mathrm{CaO} .3 \mathrm{~B}_{2} \mathrm{O}_{3} \cdot 5 \mathrm{H}_{2} 0\right)$ [14]. Nepheline syenite had a total of $18.9 \%$ fluxing oxides, including $8 \% \mathrm{Na}_{2} \mathrm{O}$ and $9.3 \% \mathrm{~K}_{2} \mathrm{O}$ compared to a total of $3 \%$ in the clay without additives (excluding $\mathrm{Fe}$ oxides).

The chemical constituents of fired ceramics revealed that, $4 \mathrm{wt} \%$ colemanite (C4W) and nepheline syenite (N4W) have approximately the same $\mathrm{SiO}_{2}$ content of 71-72 wt\% as shown in Table 32.1. The additional percentage of fluxing oxides $\left(\mathrm{Na}_{2} \mathrm{O}, \mathrm{MgO}, \mathrm{CaO}, \mathrm{K}_{2} \mathrm{O}\right)$ is expected to provide additional liquid phase during firing to improve densification at a lower temperature [15]. 


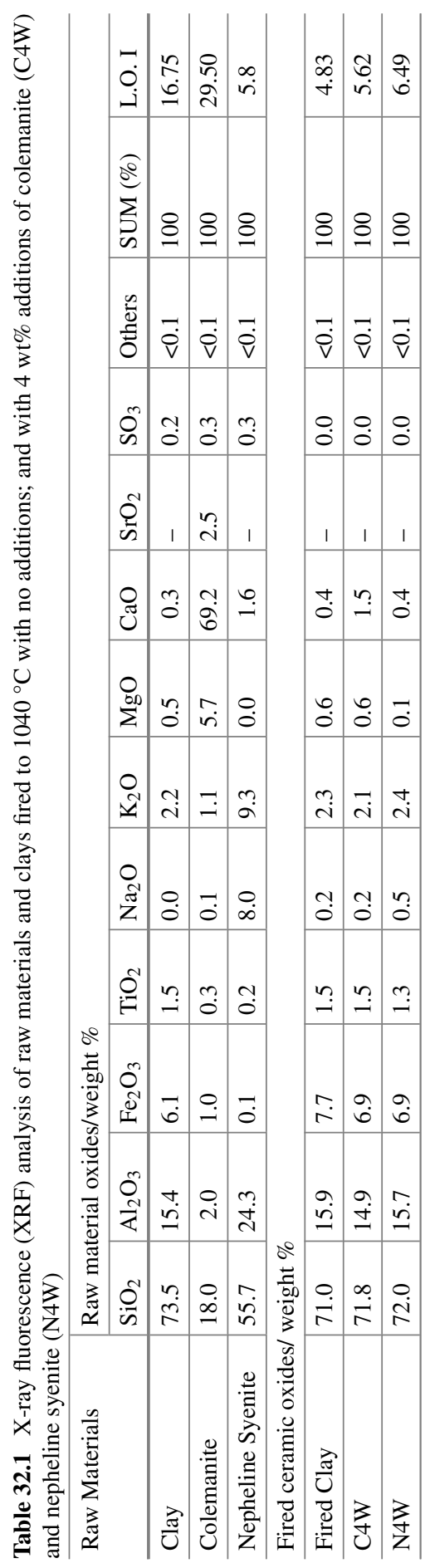




\subsubsection{Effects of Additives on Ceramic Properties}

Dilatometric curves obtained with the push rod dilatometer are shown in Figs. 32.1a-c. The $100 \%$ clay sample has almost zero coefficient of expansion between the quartz inversion $\left(581{ }^{\circ} \mathrm{C}\right)$ and around $840{ }^{\circ} \mathrm{C}$ and reached a maximum linear expansion $\left(\mathrm{dL} / \mathrm{L}_{0}\right)$ of around $0.95 \%$. This must mean that the sample is contracting due to sintering at about the same rate as it is expanding due to thermal expansion and suggests that a mechanism of shrinkage is active above $600{ }^{\circ} \mathrm{C}$. The sample then shrinks rapidly, beginning at $820^{\circ} \mathrm{C}$ and continuing up to the end of the test at $1050{ }^{\circ} \mathrm{C}$. Shrinkage of $1 \%$ (from the maximum value of $\mathrm{dL} / \mathrm{L}_{0}$ ) was achieved at a temperature of $1000{ }^{\circ} \mathrm{C}$.

For the clay with colemanite additions (Fig. 32.1b) the maximum expansion on heating was $1.5 \%, 50 \%$ higher than for the clay alone. The derivative curve shows two
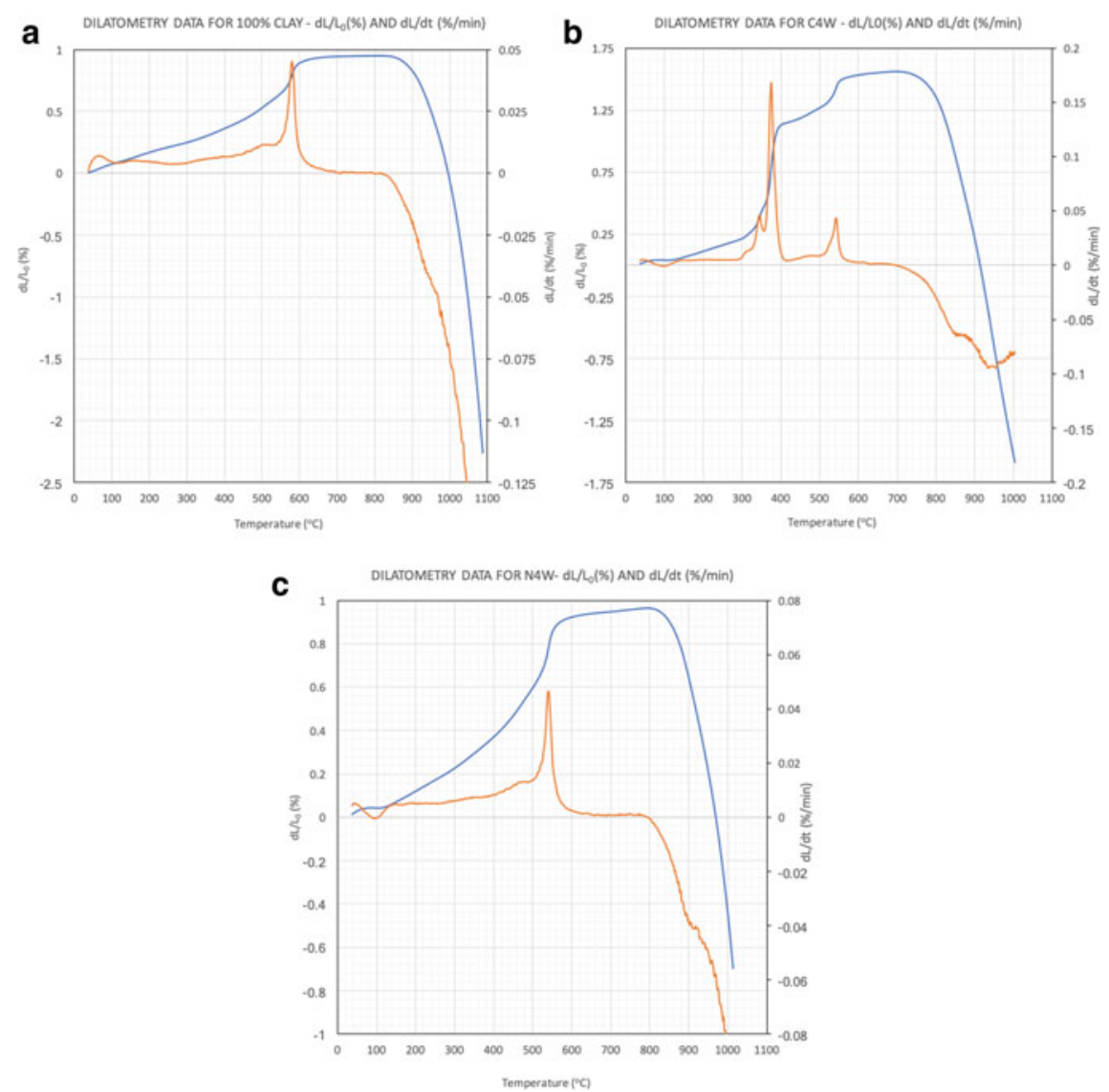

Fig. 32.1 Dilatometry results for a $100 \%$ Clay, b $4 \mathrm{wt} \%$ colemanite and $\mathbf{c} 4 \mathrm{wt} \%$ nepheline syenite, all heated to $1050{ }^{\circ} \mathrm{C}$ at $5{ }^{\circ} \mathrm{C} / \mathrm{min}$ 
Table 32.2 Data obtained from dilatometry experiments showing the effect of additives on the temperature for the onset of shrinkage and extent of shrinkage

\begin{tabular}{l|l|l|l}
\hline Sample & $\begin{array}{l}\text { Temperature for onset of } \\
\text { shrinkage }\left({ }^{\circ} \mathrm{C}\right)\end{array}$ & $\begin{array}{l}\text { Temperature for } 1 \% \\
\text { shrinkage }\left({ }^{\circ} \mathrm{C}\right)\end{array}$ & $\begin{array}{l}\text { Linear shrinkage at } \\
1000{ }^{\circ} \mathrm{C}(\%)\end{array}$ \\
\hline $100 \%$ Clay & 820 & 1000 & 1 \\
\hline C4W & 700 & 875 & 3 \\
\hline N4W & 800 & 972 & 1.4 \\
\hline
\end{tabular}

sharp peaks at $363{ }^{\circ} \mathrm{C}$ and $380{ }^{\circ} \mathrm{C}$ which are due to the decomposition of colemanite by the removal of the inter-crystallite water as reported by [10-16] leaving a glassy borate structure [14] and resulting in a rapid expansion of the body. Shrinkage begins at $700{ }^{\circ} \mathrm{C}$ and a shrinkage of $1 \%$ was achieved at a temperature of $875^{\circ} \mathrm{C}$. At 1000 ${ }^{\circ} \mathrm{C}$ the sample had undergone $3 \%$ shrinkage.

For the clay with $4 \mathrm{wt} \%$ Nepheline syenite the behaviour is similar to the $100 \%$ clay but with shrinkage beginning at $800{ }^{\circ} \mathrm{C}$ and $1 \%$ shrinkage being achieved at a temperature of $972{ }^{\circ} \mathrm{C}$. The results are summarised in Table 33.2. At $1000{ }^{\circ} \mathrm{C}$ the sample had undergone $1.4 \%$ shrinkage.

Note that due to the rate and extent of the shrinkage in C4W and N4W samples above $1000{ }^{\circ} \mathrm{C}$ the dilatometer automatically aborts the run as a safety precaution. Thus, data for $\mathrm{C} 4 \mathrm{~W}$ and $\mathrm{N} 4 \mathrm{~W}$ ends at a lower temperature than that for $100 \%$ clay.

The results above need to be treated with some caution as there is an observed variation in the temperature of the $\alpha-\beta$ quartz transition temperature. It is seen to vary from $581{ }^{\circ} \mathrm{C}$ for $100 \%$ clay to $542{ }^{\circ} \mathrm{C}$ and $555^{\circ} \mathrm{C}$ for $\mathrm{N} 4 \mathrm{~W}$ and $\mathrm{C} 4 \mathrm{~W}$, respectively. While the accepted value for pure quartz is $573{ }^{\circ} \mathrm{C}$ a value of $581{ }^{\circ} \mathrm{C}$ is consistent with other work on clays at this heating rate [17]. What is difficult to interpret are the large decreases in $\alpha-\beta$ transition temperature for the ceramic bodies fired at the same rate when the quartz is primarily from the same clay source in all samples. A discussion of possible causes is given in [18].

Volumetric shrinkage, as calculated from the change in dimensions of a cylindrical sample after firing at $1040{ }^{\circ} \mathrm{C}$ for $2 \mathrm{~h}$, gives a measure of how the additives would influence the final properties of a brick subject to a normal firing procedure. Volumetric shrinkage was $9.8 \%$ for $100 \%$ clay while it was lower, at $8.1 \%$ and 4.9\% for nepheline and colemanite additives respectively, as shown in Fig. 32.2a. Despite small increases in the fluxing oxides $\mathrm{Na}_{2} \mathrm{O}$ and $\mathrm{K}_{2} \mathrm{O}$ in the N4W sample (see Table 32.1) and the lower shrinkage onset temperature and greater extent of shrinkage shown in dilatometry (see Fig. 32.1b) the N4W samples underwent lower volumetric shrinkage than the $100 \%$ clay after $2 \mathrm{~h}$ at $1040{ }^{\circ} \mathrm{C}$ (Fig. 32.1c).

The volumetric shrinkage of $\mathrm{C} 4 \mathrm{~W}$ samples was around half that of the $100 \%$ clay and this is probably due to the effects of the colemanite decomposition between $300{ }^{\circ} \mathrm{C}$ to $400{ }^{\circ} \mathrm{C}$. The data for the samples fired at $950{ }^{\circ} \mathrm{C}$ suggest that the additional fluxing oxides in $\mathrm{C} 4 \mathrm{~W}$ and $\mathrm{N} 4 \mathrm{~W}$ samples do result in a higher volumetric shrinkage than the $100 \%$ clay at this temperature but this is not maintained to $1040{ }^{\circ} \mathrm{C}$. 


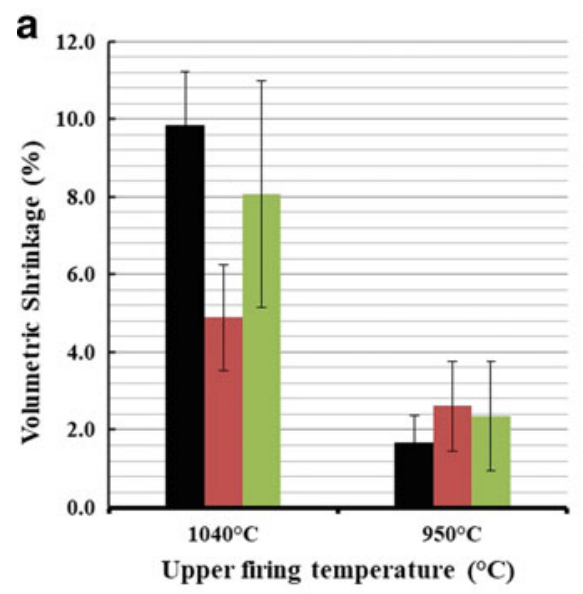

b

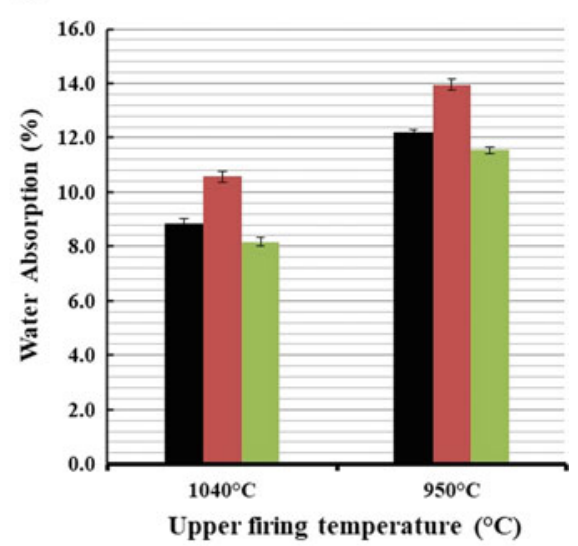

$\square 100 \%$ Clay $\square$ 4wt.\% Colemanite $₫ 4$ wt.\% Nepheline syenite

Fig. 32.2 a Volumeteric shrinkage and b boiling test result of $100 \%$ clay and clay with 4 wt $\%$ inorganic additives fired to $950{ }^{\circ} \mathrm{C}$ and $1040{ }^{\circ} \mathrm{C}$

At $950{ }^{\circ} \mathrm{C}$ the volumetric shrinkages for $\mathrm{C} 4 \mathrm{~W}$ and $\mathrm{N} 4 \mathrm{~W}$ are significantly lower than those typically observed for bricks with the required properties as shown in Fig. 32.2a.

For water absorption of samples fired at $1040^{\circ} \mathrm{C}, \mathrm{N} 4 \mathrm{~W}$ recorded the lowest absorption of $8.2 \%$ compared with $100 \%$ clay absorption of $8.8 \%$ and $\mathrm{C} 4 \mathrm{~W}$ had highest absorption of $10.6 \%$ (Fig. 32.2b). These are mostly consistent with the volumetric shrinkage data where lower shrinkage suggests a higher volume of pores in the structure which are able to absorb water. At the lower temperature of $950{ }^{\circ} \mathrm{C}$ the water absorption (Fig. 32.2b) is higher for all samples, again consistent with the lower volumetric shrinkage results and expected higher porosity at $950{ }^{\circ} \mathrm{C}$ (Fig. 32.2a).

It was noted that the dilatometry results and the volumetric expansion results appear to suggest contradictory behaviour. From dilatometry the addition of colemanite and nepheline syenite both appear to reduce the temperature at which shrinkage starts and the temperature at which $1 \%$ linear shrinkage is achieved. However, these differences do not seem to have influenced the volumetric shrinkage of the samples after firing at $1040{ }^{\circ} \mathrm{C}$ for $2 \mathrm{~h}$. For $\mathrm{C} 4 \mathrm{~W}$ samples the decomposition of the chemically bonded water in colemanite has resulted in a large expansion of the sample prior to the shrinkage and this has resulted in overall lower volumetric shrinkage. Other studies have reported a bloating effect at higher temperature as a major effect from the decomposition of calcite in colemanite which results in the release of $\mathrm{CO}_{2}$ gas [19]. For N4W samples, the additional fluxing oxides appear not to have increased the volumetric shrinkage at $1040{ }^{\circ} \mathrm{C}$ and in fact the shrinkage is lower than the $100 \%$ clay.

Results for the porosity size distribution and porosity volumes as measured by mercury porosimetry on samples fired at $1040^{\circ} \mathrm{C}$ and $950{ }^{\circ} \mathrm{C}$ are shown in Figs. 32.3 and Table 32.3 . For $1040{ }^{\circ} \mathrm{C}$ firing $\mathrm{C} 4 \mathrm{~W}$ records the lowest total intrudable porosity 

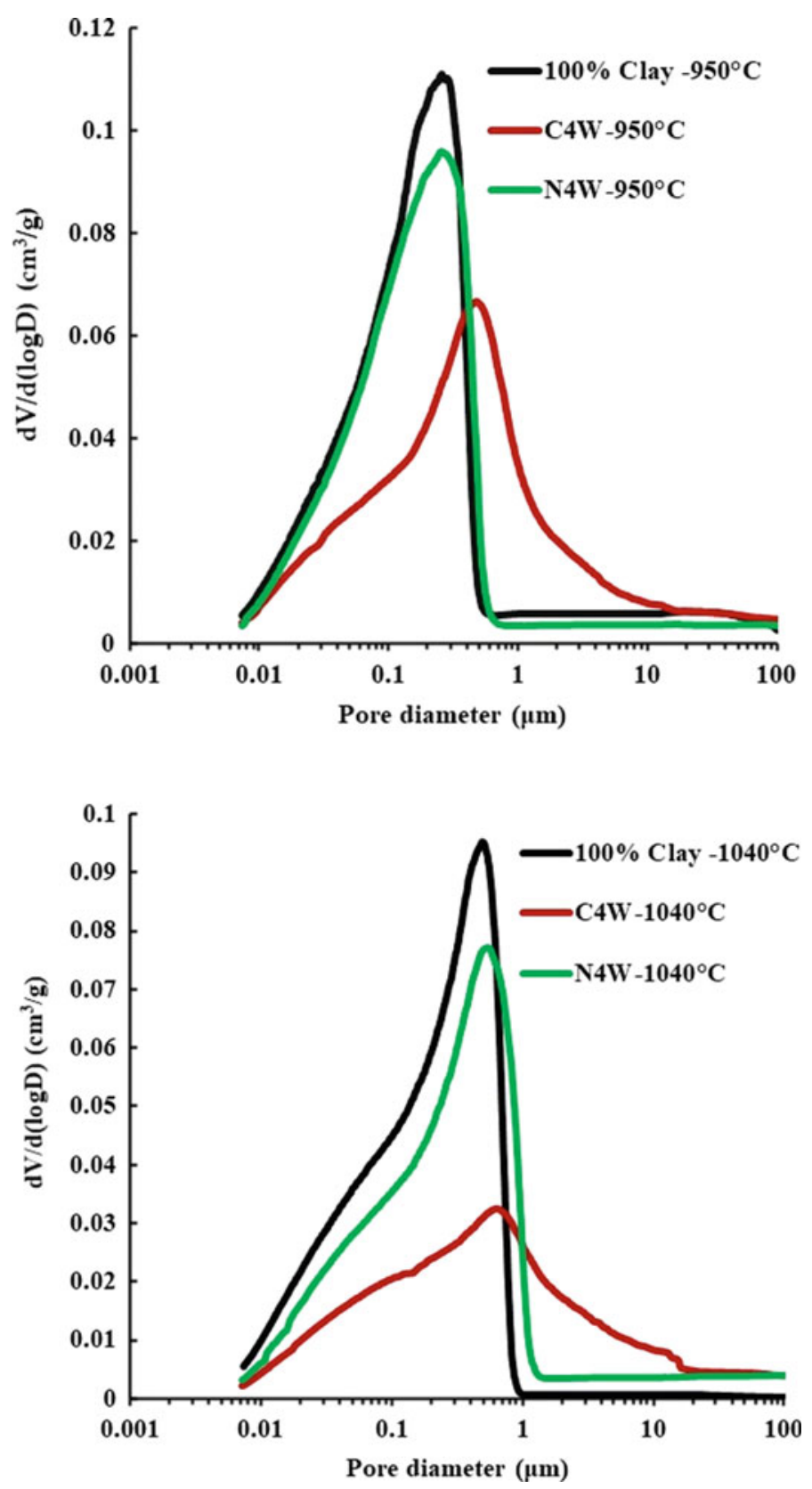

Fig. 32.3 Pore size distribution of fired clay with $4 \mathrm{wt} \%$ inorganic additives compared to $100 \%$ clay fired to $950{ }^{\circ} \mathrm{C}$ and $1040{ }^{\circ} \mathrm{C}$ 
Table 32.3 Total intrudable porosity of fired clays with 4 wt $\%$ inorganic mineral additions compared to fired $100 \%$ clay

\begin{tabular}{l|l|l}
\hline$\%$ Porosity by mercury intrusion porosimetry (MIP) \\
\hline Sample ID & Fired $950{ }^{\circ} \mathrm{C}$ & Fired $1040{ }^{\circ} \mathrm{C}$ \\
\hline $100 \%$ Clay & 18.86 & 14.20 \\
\hline C4W & 18.44 & 12.61 \\
\hline N4W & 17.58 & 14.06 \\
\hline
\end{tabular}

of $12.61 \%$ compared to $14.2 \%$ for $100 \%$ clay and $14.06 \%$ for N4W. This is in contradiction with the volumetric shrinkage and water absorption results where $\mathrm{C} 4 \mathrm{~W}$ has the lowest shrinkage and highest water absorption, suggesting that it should have around $20 \%$ more porosity than the $100 \%$ clay sample $[20,21]$.

In terms of pore size distribution (PSD) of samples fired at $1040{ }^{\circ} \mathrm{C} / 2 \mathrm{~h}$ (Fig. 32.3), the $100 \%$ clay samples had all pores smaller than $1 \mu \mathrm{m}$. There is a bi-modal PSD present, with the main peak in pore size around $0.5 \mu \mathrm{m}$ but a broad distribution of smaller pores sizes in the range $0.01-0.2 \mu \mathrm{m}$. N4W shows a very similar PSD but with some pores slightly larger than $1 \mu \mathrm{m}$ and the peak slightly shifted to larger sizes. C4W has a very different PSD, with a smaller peak at $0.7 \mu \mathrm{m}$ and a broad distribution between $0.01 \mu \mathrm{m}$ and $11 \mu \mathrm{m}$. At the lower firing temperature of 950 ${ }^{\circ} \mathrm{C}$ the PSD of $100 \%$ clay and N4W are very similar to each other but are shifted to smaller pore sizes, from about $0.5 \mu \mathrm{m}$ at $1040{ }^{\circ} \mathrm{C}$ down to $0.25 \mu \mathrm{m}$ at $950{ }^{\circ} \mathrm{C}$. The C4W PSD at $950{ }^{\circ} \mathrm{C}$ is similar to that at $1040{ }^{\circ} \mathrm{C}$ but with a shift in the main peak to smaller pore sizes $\left(0.7 \mu \mathrm{m}\right.$ at $1040{ }^{\circ} \mathrm{C}$ and $0.5 \mu \mathrm{m}$ at $\left.950{ }^{\circ} \mathrm{C}\right)$ and there appear to be fewer large pores (in the range 8 to $10 \mu \mathrm{m}$ ).

Nicholson and Ross [22] explain that in clays pore radius can increase with firing temperature while the volume of porosity decreases with a change from $0.55 \mu \mathrm{m}$ and $1.2 \mu \mathrm{m}$ for buff fired clays fired to $900{ }^{\circ} \mathrm{C}$ and $1000{ }^{\circ} \mathrm{C}$ respectively.

\subsection{Conclusions}

The use of colemanite or nepheline syenite as an addition to brick making clay has been studied and the influence of these additives on the thermal and physical properties of the resulting fired clay bodies has been investigated. The following conclusions can be drawn:

1. The use of $4 \mathrm{wt} \%$ colemanite mineral additives to brick clays resulted in the production of decomposition products $(\mathrm{OH})$ in the temperature range $300{ }^{\circ} \mathrm{C}-400$ ${ }^{\circ} \mathrm{C}$ which created a large and rapid expansion $\left(0.75 \%\right.$ linear over a $100{ }^{\circ} \mathrm{C}$ range $)$ of the clay body. The introduction of $\mathrm{Ca}$ and $\mathrm{B}$ appeared to reduce the temperature for the onset of shrinkage by $120^{\circ} \mathrm{C}$ and result in a linear shrinkage at $1000{ }^{\circ} \mathrm{C}$ three times higher than that of the $100 \%$ clay. However, when fired at $1040^{\circ} \mathrm{C} / 2 \mathrm{~h}$ the clay body containing colemanite produced only half the volumetric shrinkage 
compared with the $100 \%$ clay (4.9\% vs. $9.8 \%$ ). It also had a higher average pore size and pores sizes between $1 \mu \mathrm{m}$ and $10 \mu \mathrm{m}$, which were not observed in the $100 \%$ clay. As a result, the water absorption was higher than the $100 \%$ clay $(11 \%$ vs. $9 \%$ ).

2. The use of nepheline syenite at $4 \mathrm{wt} \%$ introduced small amounts of additional fluxing oxides $\left(\mathrm{Na}_{2} \mathrm{O}, \mathrm{K}_{2} \mathrm{O}\right)$ which could be expected to enhance the sintering of the brick clay at the firing temperature through the formation of more lower melting point phases. Dilatometry showed a reduction of around $20{ }^{\circ} \mathrm{C}$ in the shrinkage onset temperature and $1 \%$ linear shrinkage was achieved $28{ }^{\circ} \mathrm{C}$ lower than for the $100 \%$ clay. The linear shrinkage at $1000{ }^{\circ} \mathrm{C}$ was $1.4 \%$, which was higher than for the $100 \%$ clay. However, volumetric shrinkage of N4W fired at $1040{ }^{\circ} \mathrm{C} / 2 \mathrm{~h}$ was lower than for the $100 \%$ clay $(9.8 \%$ vs. $8.1 \%)$ but water absorption was also lower (8.2\% vs. $8.8 \%$ ). Pore size distribution for N4W was similar to that for the $100 \%$ clay and no pores larger than around $1.5 \mu \mathrm{m}$ were present. Thus, nepheline syenite at $4 \mathrm{wt} \%$ is shown to have small but measurable effects on the thermal behaviour of brick clays. However, under the conditions used it did not result in significant changes in volumetric shrinkage or water absorption which would have indicated that lower temperatures or times could be used in production.

3. Whether the properties of clays with either the $\mathrm{C} 4 \mathrm{~W}$ or the N4W compositions are suitable for the production of bricks for construction purposes requires further testing but the observed reductions in the shrinkage onset temperature and the greater extent of the shrinkage around $1000{ }^{\circ} \mathrm{C}$ for nepheline syenite may be useful phenomena to exploit further in order to reduce energy use and emissions, especially since both these materials can be sourced as wastes from other processes, leading to a further reduction in the environmental burden.

Acknowledgements The authors would like to thank Wienerberger Ltd. for providing the raw material (clay) and funding this research with Sheffield Hallam University.

\section{References}

1. Vogl, Ceramic roadmap 2050—Whitewares' contribution 90, pp. E34-E38 (2013)

2. D.G. WSP PB, Decarbonisation, Industrial Roadmap, Energy Efficiency Plan, Action, no. October, 2017

3. N.V. Boltakova, G.R. Faseeva, R.R. Kabirov, R.M. Nafikov, Y.A. Zakharov, Utilization of inorganic industrial wastes in producing construction ceramics. Review of Russian experience for the years 2000-2015. Waste Manag. 60, 230-246 (2017). https://doi.org/10.1016/j.wasman. 2016.11.008

4. A.B. Dondi, M. Marsigli, Fabbri, Review recycling of industrial and urban wastes in brick Production. 13(3), 218-225 (1997)

5. A.K. Abdurakhmanov, A.M. Éminov, G.N. Maslennikova, Stages of ceramic structure formation in the presence of additives. Glass Ceramics (English Translation of Steklo i Keramika) 57(9-10), 354-356 (2000). https://doi.org/10.1023/A:1007150606044 
6. E. Lewicka, Conditions of the feldspathic raw materials supply from domestic and foreign sources in Poland. Gospodarka Surowcami Mineralnymi/Mineral Resources Management 26(4), 5-19 (2010)

7. J. Pranckevičiene, V. Balkevičius, A.A. Špokauskas, Investigations on properties of sintered ceramics out of low-melting illite clay and additive of fine-dispersed nepheline syenite. Medziagotyra 16(3), 231-235 (2010)

8. M.U. Rehman, M. Ahmad, K. Rashid, Influence of fluxing oxides from waste on the production and physico-mechanical properties of fired clay brick: a review. J. Build. Eng. 27, 100965 (2020). https://doi.org/10.1016/j.jobe.2019.100965

9. J. Everhart, J. Lawson Felder, Process for fast-fire ceramic tile using nepheline syenite and clay (1972)

10. R.L. Frost, R. Scholz, X. Ruan, R.M.F. Lima, Thermal analysis and infrared emission spectroscopy of the borate mineral colemanite $\left(\mathrm{CaB}_{3} \mathrm{O}_{4}(\mathrm{OH})_{3} \cdot \mathrm{H}_{2} \mathrm{O}\right)$ : Implications for thermal stability. J. Therm. Anal. Calorim. 124(1), 131-135 (2016). https://doi.org/10.1007/s10973015-5128-5

11. A. Yamık, İ. Bentli, C. Karagüzel, M. Çınar, B. Cengiz, The Application of Colemanite Addition to Floor Tile Glazes, pp. 753-756 (2001)

12. S. Akpinar, A. Evcin, Y. Ozdemir, Effect of calcined colemanite additions on properties of hard porcelain body. Ceram. Int. 43(11), 8364-8371 (2017). https://doi.org/10.1016/j.ceramint. 2017.03.178

13. A.M.T. Bell et al., X-ray Fluorescence Analysis of Feldspars and Silicate Glass Effects of Melting Time on Fused Bead Consistency and Volatilisation, pp. 1-17 (2020)

14. A. Rusen, Investigation of structural behavior of colemanite depending on temperature. Revista Romana de Materiale/Romanian J. Mater. 48(2), 245-250 (2018)

15. R.G. Frizzo, A. Zaccaron, V. de Souza Nandi, A.M. Bernardin, Pyroplasticity on porcelain tiles of the albite-potassium feldspar-kaolin system: a mixture design analysis. J. Build. Eng. 31, 101432 (2020). https://doi.org/10.1016/j.jobe.2020.101432

16. I. Waclawska, L. Stoch, J. Paulik, F. Paulik, Thermal decomposition of colemanite. Thermochimica Acta 126(C), 307-318 (1988). https://doi.org/10.1016/0040-6031(88)87276-9

17. L. Beddiar, F. Sahnoune, M. Heraiz, D. Redaoui, Thermal transformation of fired clay ceramics by dilatometric analysis. Acta Phys. Pol. A 134(1), 86-89 (2018). https://doi.org/10.12693/APh ysPolA.134.86

18. F.C. Kracek, The polymorphism of sodium sulfate (1927). https://doi.org/10.1021/j150303a001

19. N. Ediz, A. Yurdakul, Characterization of porcelain tile bodies with colemanite waste added as a new sintering agent. J. Ceramic Process. Res. 10(4), 414-422 (2009)

20. H. Giesche, Mercury porosimetry: a general (practical) overview. Part. Part. Syst. Charact. 23(1), 9-19 (2006). https://doi.org/10.1002/ppsc.200601009

21. K.K. Aligizaki, Pore Structure of Cement-based Materials: Testing, Interpretation and Requirements. Crc Press (2005)

22. P.S. Nicholson, W.A. Ross, Kinetics of oxidation of natural organic material in clays. J. Am. Ceram. Soc. 53(3), 154-158 (1970). https://doi.org/10.1111/j.1151-2916.1970.tb12058.x 
Open Access This chapter is licensed under the terms of the Creative Commons Attribution 4.0 International License (http://creativecommons.org/licenses/by/4.0/), which permits use, sharing, adaptation, distribution and reproduction in any medium or format, as long as you give appropriate credit to the original author(s) and the source, provide a link to the Creative Commons license and indicate if changes were made.

The images or other third party material in this chapter are included in the chapter's Creative Commons license, unless indicated otherwise in a credit line to the material. If material is not included in the chapter's Creative Commons license and your intended use is not permitted by statutory regulation or exceeds the permitted use, you will need to obtain permission directly from the copyright holder.

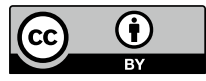

